\title{
Long-term natural history and complications of collagenous colitis
}

\author{
Hugh J Freeman MD CM FRCPC
}

\begin{abstract}
HJ Freeman. Long-term natural history and complications of collagenous colitis. Can J Gastroenterol 2012;26(9):627-630.
\end{abstract}

Microscopic forms of colitis have been described, including collagenous colitis, a possibly heterogeneous disorder. Collagenous colitis most often appears to have an entirely benign clinical course that usually responds to limited treatment. Sometimes significant extracolonic disorders, especially arthritis, spondylitis, thyroiditis and skin disorders, such as pyoderma gangrenosum, dominate the clinical course and influence the treatment strategy. However, rare fatalities have been reported and several complications, some severe, have been attributed directly to the colitis. Toxic colitis and toxic megacolon may develop. Concomitant gastric and small intestinal inflammatory disorders have been described including celiac disease and more extensive collagenous inflammatory disease. Colonic ulceration has been associated with the use of nonsteroidal anti-inflammatory drugs, while other forms of inflammatory bowel disease, including ulcerative colitis and Crohn disease, may evolve directly from collagenous colitis. Submucosal 'dissection', colonic fractures, or mucosal tears and perforation, possibly from air insufflation during colonoscopy, have been reported. Similar changes may result from increased intraluminal pressures that may occur during radiological imaging of the colon. Neoplastic disorders of the colon may also occur during the course of collagenous colitis, including colon carcinoma and neuroendocrine tumours (ie, carcinoids). Finally, lymphoproliferative disease has been reported.

Key Words: Cat scratch colon; Celiac disease; Collagenous gastritis; Collagenous sprue; Colon cancer; Colonic fractures; Colonic perforation; Microscopic colitis

Oollagenous colitis was first independently described in January 1976 in Canada and Sweden (1,2). In both reports, a watery diarrhea syndrome was described in a total of three females. In all of these cases, distinctive histopathological changes consisting of an inflammatory process in the colonic mucosa with characteristic subepithelial hyaline deposits in the lamina propria region were reported $(1,2)$. These pathological features appeared to be similar to small bowel changes described earlier in collagenous sprue (3). Most often, colonoscopic evaluation is virtually normal and colonic biopsies are required to establish a diagnosis (Figures 1A and 1B). Ultrastructural studies of these trichrome-positive colonic deposits also showed that collagen was present (1). These electron microscopic findings were later confirmed by other investigators (4). Subsequent clinical studies on collagenous colitis, along with fundamental research investigations published during the ensuing three decades, have been previously extensively reviewed elsewhere (5).

In large clinical series, primarily from registries originating in Scandanavian centres, middle-age to elderly females were primarily affected $(6,7)$, although children with collagenous colitis have also been reported $(8,9)$. Other primate species, specifically baboons, have also demonstrated the typical histopathological colonic changes (10).

Curiously, pathological findings in the colonic mucosa from a mass stranding of five melon-headed whales in Florida (USA) showed

\section{L'évolution naturelle et les complications à long terme de la colite collagène}

Il existe des formes microscopiques de colite, y compris la colite collagène, un trouble peut-être d'origine hétérogène. La plupart du temps, la colite collagène semble avoir une évolution clinique complètement anodine, qui réagit généralement à un traitement limité. Il arrive que de graves troubles extracoliques, notamment l'arthrite, la spondylite, la thyroïdite et les troubles cutanés tels que le pyoderma gangrenosum, dominent l'évolution clinique et influent sur la stratégie thérapeutique. Toutefois, de rares décès ont été déclarés et plusieurs complications, quelquefois graves, sont directement attribuées à la colique. Une colite toxique et un mégacôlon toxique peuvent se manifester. Des troubles inflammatoires concomitants peuvent se déclarer dans l'estomac et l'intestin grêle, y compris la maladie cœliaque et une maladie inflammatoire collagène plus étendue. L'ulcération du côlon s'associe à l'utilisation d'anti-inflammatoires non stéroïdiens, tandis que d'autres formes de maladies inflammatoires de l'intestin, y compris la colite ulcéreuse et la maladie de Crohn, peuvent évoluer directement de la colite collagène. Des cas de « dissection » submuqueuse, de fractures du côlon ou de déchirures et de perforations de la muqueuse, peut-être causées par l'insufflation d'air pendant la coloscopie, ont été observés. Des modifications similaires peuvent découler d'une pression accrue à l'intérieur de la lumière, laquelle peut se produire pendant l'imagerie radiologique du côlon. On peut également constater des troubles néoplasiques du côlon pendant l'évolution de la colite collagène, y compris un carcinome du côlon et des tumeurs neuroendocriniennes (c.-à-d., carcinoïdes). Enfin, une maladie lymphoproliférative a été déclarée.

striking features of collagenous colitis in each of these aquatic mammals (11). These observations in different age groups and across different mammalian species suggest that the etiology and pathogenesis of this disorder or group of disorders are quite heterogeneous.

Collagenous colitis also occurs in a wide variety of clinical settings (Table 1). Based on sequential biopsy studies, some have suggested that this disorder may evolve from another form of microscopic colitis, so-called lymphocytic colitis, into collagenous colitis (12). Moreover, both collagenous colitis (13) and lymphocytic colitis (14) may be associated with celiac disease and the use of a broad range of medications, particularly commonly-used nonsteroidal anti-inflammatory drugs (15) and proton pump inhibitors, especially lansoprazole (16). There are also reports suggesting that collagenous colitis may be precipitated by infections, specifically Yersinia species or, possibly, bacterial toxins (17-20). Finally, there are familial cases suggesting that genetic or heritable factors play a role (21).

\section{LONG-TERM NATURAL HISTORY}

The natural history of this disorder has been difficult to document. Recent long-term studies of collagenous colitis have suggested that the disorder usually runs a benign clinical course, at least during evaluation over a period of approximately 10 years (22). In most individuals, symptoms resolve with no treatment or remission occurs

Department of Medicine (Gastreonterology), University of British Columbia, Vancouver, British Columbia

Correspondence: Dr Hugh J Freeman, University of British Columbia Hospital, 2211 Wesbrook Mall, Vancouver, British Columbia V6T 1 W5.

Telephone 604-822-7216, fax 604-822-7236, e-mail hugfree@shaw.ca

Received for publication January 29, 2012. Accepted February 1, 2012 


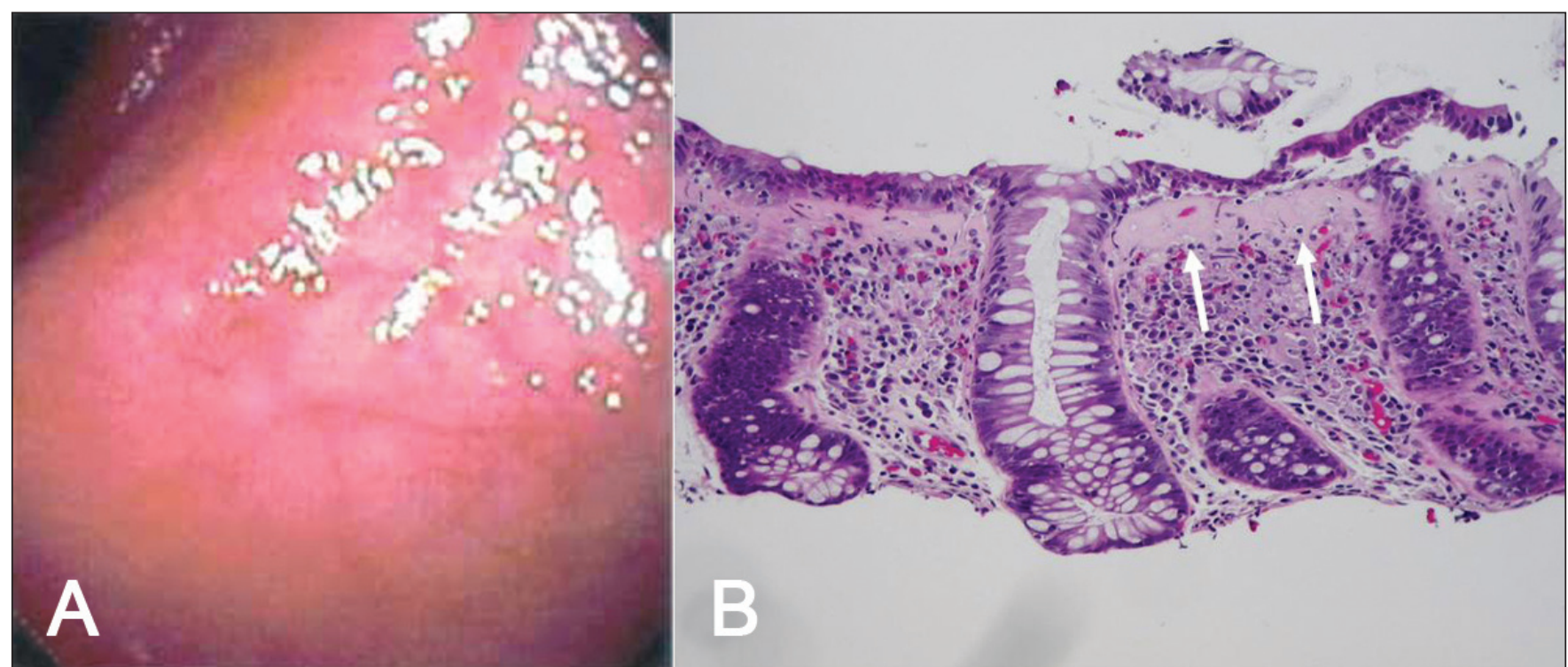

Figure 1) A Colonoscopic image of collagenous colitis showing minimal mucosal change with patchy appearance of normal vascular pattern. B Histopathological changes of collagenous colitis. The most distinctive feature is the presence of a band-like deposit (arrows) with entrapped lamina propria cells. Other important components include increased number of inflammatory cells in the lamina propria and intraepithelial lymphocytes. Some surface epithelial cells appear to have separated or sloughed from the mucosa - an important histopathological feature for the diagnosis of collagenous colitis

\section{TABLE 1}

\section{Causes of collagenous colitis}

\section{Idiopathic}

Possible evolution from lymphocytic colitis

Celiac disease

Medications (eg, nonsteroidal anti-inflammatories, proton pump inhibitors)

Associated collagenous gastritis or collagenous enteritis (sprue)

Possible enteric infections or toxins

Familial forms

with minimal therapy only. In some, however, persistent diarrhea or intermittent periods of recurrent diarrhea develop, which require ongoing medication.

Because spontaneous resolution has been noted, evaluation of the clinical response to different forms of treatment may become more difficult. Even histological end points are difficult to evaluate because the subepithelial collagen deposits tend to be patchy and variable in depth, or focal in some parts of the colon, rather than diffuse and continuous in mucosal distribution (5). Treatment has usually focused on symptom resolution using added dietary fibre, nonspecific antidiarrheal agents and anti-inflammatory medications (ie, specifically, 5-aminosalicylate-containing drugs); however, data on these therapies remain limited. Steroids, particularly delayed-release budesonide, have been reported to provide symptomatic benefit in clinical trials (23). With more refractory symptoms, however, some have empirically used other immunosuppressive $(24,25)$ or even biological agents $(26)$.

Rarely, surgical treatment has also been described (27). A surgical approach is not generally recommended but does have some historical interest. Indeed, ileostomy and sigmoidostomy were reported to lead to both clinical and histological remission. Later ostomy closures, however, led to recurrent symptoms and redevelopment of collagen deposits. Possibly, a diverted noxious luminal factor was important in pathogenesis (28). Finally, collagenous pouchitis (29) and collagenous cuffitis (30) have also been described after proctocolectomy and staged reconstruction for ulcerative colitis.

\section{COMPLICATIONS}

Other 'immune-mediated' disorders have been linked to collagenous colitis including several extraintestinal disorders such as arthritis, spondylitis and thyroiditis, and dermatological disorders including pyoderma gangrenosum. Most intriguing, however, are disorders that often appear elsewhere in the gastrointestinal tract during the clinical course of collagenous colitis. For example, in a consecutive series of patients diagnosed with collagenous colitis, celiac disease was subsequently detected in more than $20 \%$ (13). This could have implications for patients with celiac disease not appearing to respond to a glutenfree diet. In these individuals, the colonic disease - rather than celiac disease - may be the cause of symptoms. Collagenous involvement of the gastric (ie, collagenous gastritis) and/or small intestinal mucosa (ie, collagenous enteritis) has also been detected with collagenous colitis suggesting that, in some individuals, histological changes may not be simply localized in the colon but may be reflective of a far more extensive inflammatory process $(31,32)$. Even with extensive collagenous involvement of the intestinal tract, however, complete histological remission has been demonstrated (32).

While most patients with collagenous colitis have a benign or sometimes relapsing and remitting course, awareness of more worrisome, albeit apparently unusual, complications has increased. Indeed, a severe and protracted course may develop and, in at least one report, a fatal outcome directly attributed to the colitis has been recorded (33). Surface epithelial cell sloughing may be appreciated in colonic biopsies, leaving a subepithelial deposit 'naked' to the luminal environment; in this setting, mucosal permeability may be substantially altered and protein-losing enteropathy has been noted in the absence of small intestinal disease (34). Colonic ulceration may also occur, possibly related to concomitant use of medications, specifically nonsteroidal anti-inflammatory drugs (35). Severe or toxic colitis as well as toxic megacolon have been reported, similar to other forms of inflammatory bowel disease.

Indeed, a relationship with other forms of inflammatory bowel disease has been occasionally recorded but this appears to be uncommon. Superficial mucosal giant cells directly associated with the collagen deposits have been occasionally described (36) and, in some, collagenous colitis may progress into frank Crohn disease or evolve into severe ulcerative colitis (37-39). In one report describing progression to severe ulcerative colitis necessitating colectomy, complete disappearance of pre-existent collagen deposits was noted in the resected colon (39).

Other apparently unusual colonic complications have been recorded, possibly directly related to investigative procedures. This has been described as so-called submucosal 'dissection' (40). Colonic 'fracturing' 
after endoscopic instrumentation, possibly related to air insufflation and barotrauma, or insertion of barium contrast agents, has been reported (41). Recently, a highly descriptive report entitled 'Cat scratch colon' emphasized the macroscopic changes sometimes observed during colonoscopy in collagenous colitis (42). Spontaneous peritonitis with colonic perforation has also been recorded (43). In all of these reports, it was hypothesized that the integrity of the colonic wall may be compromised owing to submucosal collagen deposition. Their significance to the endoscopist is obvious, particularly if no substantive macroscopic changes are initially appreciated during the course of an investigation for a chronic watery diarrhea syndrome.

A particularly striking finding is the rarity of reported malignant disease complicating the clinical course of collagenous colitis. Colorectal cancer has been noted (44), including cecal cancer (45), but these may have been only coincidental. In an extensive survey study, the overall risk of colorectal cancer was similar to the general control population; only two patients with collagenous colitis were seen with colorectal cancer, but these occurred before the development of colitis (46). In one, concomitant collagenous involvement of the small and large intestine resolved completely following resection of a localized colon cancer, suggesting an unusual histopathological paraneoplastic phenomenon (47). Other neoplasms that have been rarely recorded include lymphoproliferative disorders $(48,49)$ and carcinoids (50). Because this is a relatively 'new' disease, sufficient time may not yet have passed to observe different superimposed disease complications, particularly malignancies. Alternatively, factors linked to pathogenesis, such as the use of nonsteroidal antiinflammatory drugs, may induce a chemopreventive effect on the development of colonic neoplastic disorders.

\section{REFERENCES}

1. Freeman HJ, Weinstein WM, Shnitka TK, Wensel RH, Sartor VE. Watery diarrhea syndrome associated with a lesion of the colonic basement membrane-lamina propria interface. Ann R Coll Phys Surg Can 1976;9:45.

2. Lindstrom CG. Collagenous colitis with watery diarrhea - a new entity? Pathol Eur 1976;11:87-9.

3. Weinstein WM, Saunders DR, Tytgat GN, Rubin CE. Collagenous sprue - an unrecognized type of malabsorption. N Engl J Med 1970;283:1297-301.

4. Widgren S, Jlidi R, Cox JN. Collagenous colitis: Histologic, morphometric, immunohistochemical and ultrastructural studies. Report of 21 cases. Virchows Arch 1988;413:287-96.

5. Freeman HJ. Collagenous mucosal inflammatory disorders of the gastrointestinal tract. Gastroenterology 2005;129:338-50.

6. Olesen M, Eriksson S, Bohr J, Jarnerot G, Tysk C. Microscopic colitis: A common diarrheal disease. An epidemiological study in Orebro, Sweden 1993-1996. Gut 2004;53:246-50.

7. Agnarsdottir M, Gunnlaugsson O, Orvar KB, et al. Collagenous and lymphocytic colitis in Iceland. Dig Dis Sci 2002; 47:1122-8.

8. Busuttil A. Collagenous colitis in a child. Am J Dis Child 1989;143: 998-1000.

9. Gremse DA, Boudreaux CW, Manci EA. Collagenous colitis in children. Gastroenterology 1993;104:906-9.

10. Rubio CA, Hubbard GB. Chronic colitis in baboons (similarities with chronic colitis in humans). In Vivo 2001:15:109-16.

11. Bossart GD, Hansen L, Goldstein JD, et al. Pathological findings in a rare mass stranding of melon-headed whales (Peponocephala electra) in Florida. Aquatic Mammals 2007:33-235-40.

12. Shaz BH, Reddy SI, Ayata G, et al. Sequential clinical and histopathological changes in collagenous and lymphocytic colitis over time. Mod Pathol 2004;17:395-401.

13. Freeman HJ. Collagenous colitis as the presenting feature of biopsydefined celiac disease. J Clin Gastroenterol 2004;38:664-8.

14. Wolber R, Owen D, Freeman HJ. Colonic lymphocytosis in patients with celiac sprue. Hum Pathol 1990;21:1092-6.

15. Al-Ghamdi MY, Malatjalian DA, Veldhuyzen van Zanten S. Recurrent collagenous colitis following repeated use of NSAIDs. Can J Gastroenterol 2002;16:861-2.

16. Wilcox GM, Mattia A. Collagenous colitis associated with lansoprazole. J Clin Gastroenterol 2002;34:164-6.

17. Bohr J, Nordfeith R, Jarnerot G, Tysk C. Yersinia species in collagenous colitis: A serologic study. Scand J Gastroenterol 2002;37:711-4.

18. Makinen M, Niemela S, Lehtola J, Karttunen TJ. Collagenous colitis and Yersinia enterocolitica infection. Dig Dis Sci 1998;43:1341-6.

19. Navarro-Llavat M, Domenech E, Masnou H, et al. Collagenous duodeno-ileo-colitis with transient IgG deficiency preceded by Yersinia enterocolitica intestinal infection: Case report and review of literature. Gastroenterol Hepatol 2007;30:219-21.

20. Andersen T, Andersen JR, Tvede M, Franzmann MB. Collagenous colitis: Are bacterial cytotoxins responsible? Am J Gastroenterol 1993;88:375-7.

21. van Tilburg AJ, Lam HG, Siendenrijk CA, et al. Familial occurrence of collagenous colitis. A report of two families. J Clin Gastroenterol 1990;12:2779-85.
22. Madisch A, Miehlke S, Lindner M, Bethke B, Stolte M. Clinical course of collagenous colitis over a period of 10 years. Z Gastroenterol 2006;44:971-4.

23. Chande N, McDonald JW, Macdonald JK. Interventions for treating collagenous colitis. Cochrane Database Syst Rev 2008;2:CD003575.

24. Vennamaneni SR, Bonner GF. Use of azathioprine or 6-mercaptopurine for treatment of steroid-dependent lymphocytic or collagenous colitis. Am J Gastroenterol 2001;96:2798-9.

25. Riddell J, Hillman L, Chiragakis L, Clarke A. Collagenous colitis: Oral low-dose methotrexate for patients with difficult symptoms. Long-term outcomes. J Gastroenterol Hepatol 2007;22:1589-93.

26. Munch A, Ignatova S, Strom M. Adalimumab in budesonide and methotrexate refractory collagenous colitis. Scand J Gastroenterol 2012;47:59-63.

27. Williams RA, Gelfand DV. Total proctocolectomy and ileal pouch anal anastomosis to successfully treat a patient with collagenous colitis. Am J Gastroenterol 2000;95;2147.

28. Jarnerot G, Tysk C, Bohr J, Eriksson S. Collagenous colitis and fecal stream diversion. Gastroenterology 1995;109:449-55.

29. Shen B, Bennett AE, Fazio VW, et al. Collagenous pouchitis. Dig Liver Dis 2006;38:704-9.

30. Shen B, Liu X. De novo collagenous cuffitis. Inflamm Bowel Dis 2011;17:1249-50.

31. Pulimood AB, Ramakrishna BS, Mathan MM. Collagenous gastritis and collagenous colitis: A report with sequential histological and ultrastructural findings. Gut 1999;44:881-5.

32. Freeman HJ, Davis JE, Myers DM. Complete histological resolution of collagenous sprue. Can J Gastroenterol 2004;18:333-6.

33. Widgren S, MacGee W. Collagenous colitis with protracted course and fatal evolution. Report of a case. Pathol Res Pract 1990;87:703-9.

34. Stark ME, Batts KP, Alexander GL. Protein-losing enteropathy with collagenous colitis. Am J Gastroenterol 1992;87:780-3.

35. Kakar S, Pardi DS, Burgart LJ. Colonic ulcers accompanying collagenous colitis: Implication of nonsteroidal anti-inflammatory drugs. Am J Gastroenterol 2003;98:1834-7.

36. Freeman HJ, Nimmo M. Carpet-like polypoid lesion in collagenous colitis with mucosal giant cells. Can J Gastroenterol 2011;25:187-8.

37. Chandratre S, Bramble MG, Cooke WM, Jones RA. Simultaneous occurrence of collagenous colitis and Crohn's disease. Digestion 1987;36:55-60.

38. O'Beirne JP, Ireland A. Progession of collagenous colitis to Crohn's disease. Eur J Gastroenterol Hepatol 2005;17:573-5.

39. Freeman HJ, Berean KW, Nimmo M. Evolution of collagenous colitis into severe and extensive ulcerative colitis. Can J Gastroenterol 2007;21:315-8.

40. Mitchell JD, Teague R, Bolton R, Lowes J. Submucosal "dissection” in collagenous colitis. Gut 2004;53:470.

41. Sherman A, Ackert J, Rajapaksa R, West AB, Owelty T. Fractured colon: An endoscopically distinctive lesion associated with colonic perforation following colonoscopy in patients with collagenous colitis. J Clin Gastroenterol 2004;38:341-5.

42. McDonnell WM, Loura F, Pointon MJ, Greenson JK. Cat scratch colon. Endoscopy 2007;39:459-61. 
43. Freeman HJ, James D, Mahoney CJ. Spontaneous peritonitis from perforation of the colon in collagenous colitis. Can J Gastroenterol 2001;15:265-7.

44. Gardiner GW, Goldberg R, Currie D, Murray D. Colonic carcinoma associated with an abnormal collagen table. Collagenous colitis. Cancer 1984;54:2973-7.

45. Alikhan M, Cummings OW, Rex D. Subtotal colectomy in a patient with collagenous colitis associated with colonic carcinoma and systemic lupus erythematosus. Am J Gastroenterol 1997;92:1213-5.

46. Chan JL, Tersmette AC, Offerhaus GJ, Gruber SB, Bayless TM, Giardiello FM. Cancer risk in collagenous colitis. Inflamm Bowel Dis 1999;5:40-3.
47. Freeman HJ, Berean KW. Resolution of paraneoplastic collagenous enterocolitis after resection of colon cancer. Can J Gastroenterol 2006;20:357-60.

48. Edwards DB. Collagenous colitis and histiocytic lymphoma. Ann Intern Med 1989;111:260-1.

49. Freeman HJ. Lymphoproliferative disorders in collagenous colitis. Inflamm Bowel Dis 2005;11:781-2.

50. Nussinson E, Samara M, Vigder L, Shafer I, Tzur N. Concurrent collagenous colitis and multiple ileal carcinoids. Dig Dis Sci 1988;33:1040-4. 


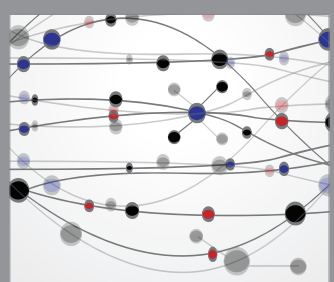

The Scientific World Journal
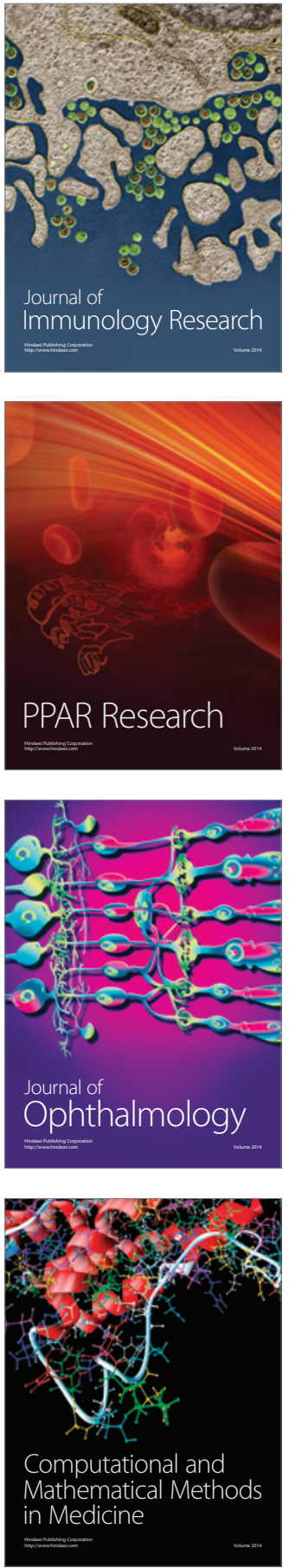

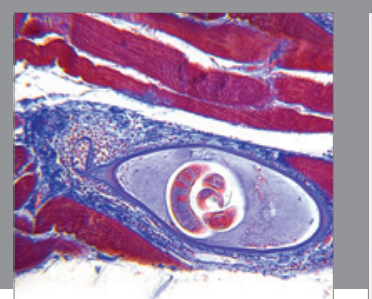

Gastroenterology Research and Practice

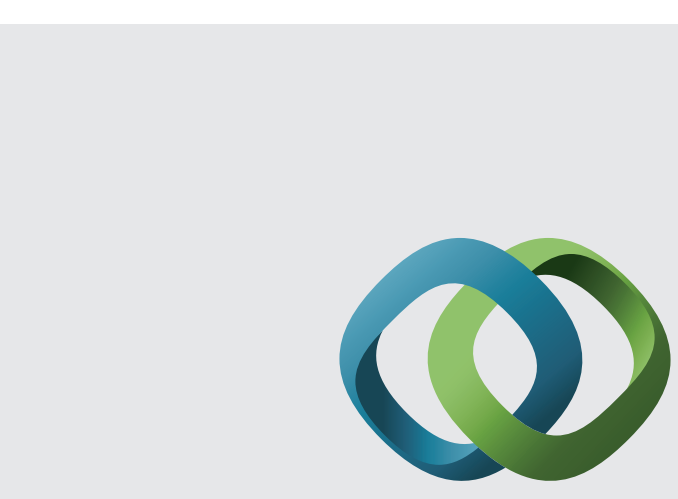

\section{Hindawi}

Submit your manuscripts at

http://www.hindawi.com
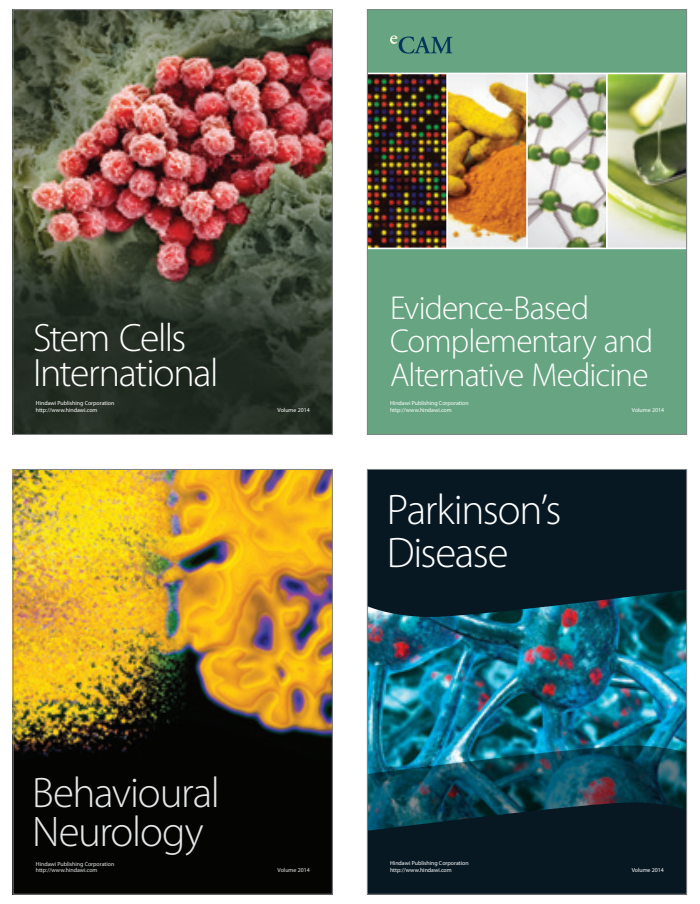
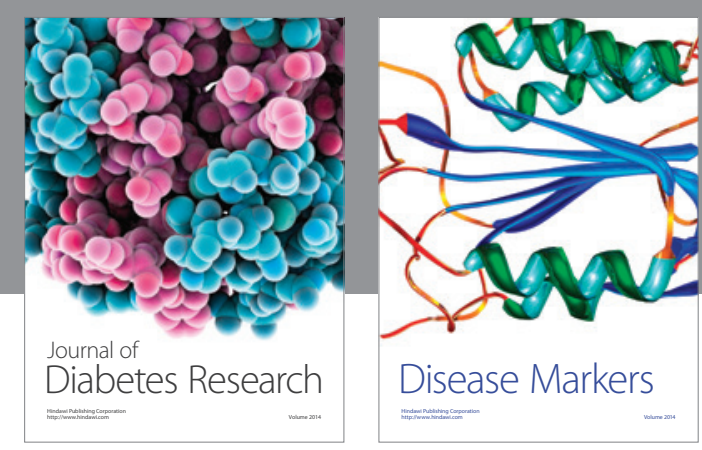

Disease Markers
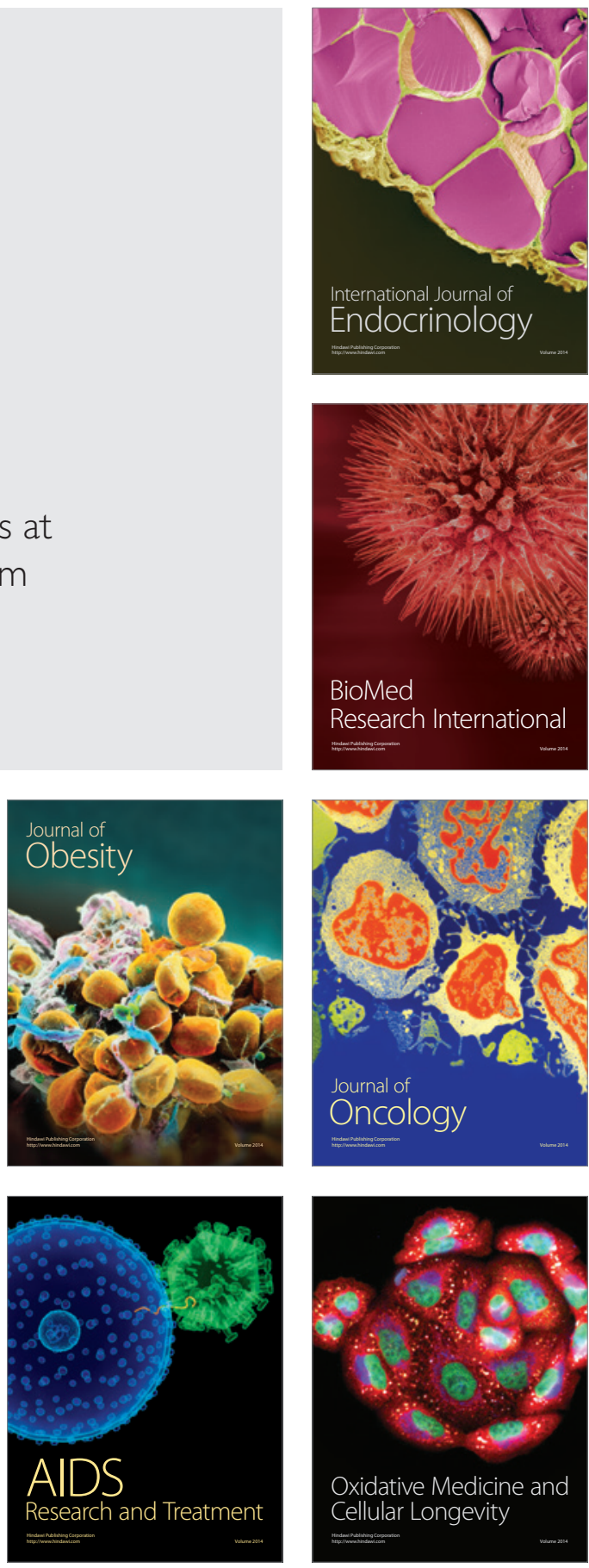